\title{
Pengaruh Kemampuan Berpikir Divergen dan Kemandirian Belajar terhadap Hasil Belajar Matematika Siswa
}

\author{
J. Rauf ${ }^{1}$, S.N.H. Halim², R.S. Mahmud ${ }^{3 *}$ \\ 1,2,3 Pendidikan Matematika, FKIP, Universitas Muhammadiyah Makassar, Makassar \\ *email: randy@unismuh.ac.id
}

\begin{abstract}
The aim of this study to know the influence of divergent thinking ability and self reliance learning towards students learning results. This is an ex-post facto research, the samples was 102 students from ninth class SMPN 24 Makassar. The instruments was divergent thinking skills test, koesioner self reliance learning, and test of student's mathematical learning results. The results of a descriptive analysis showed that the ability to think divergent students in middle category with average score 55.91, standard deviation 10.623 of the 100 ideal score with percentage $42.42 \%$. The self reliance of learning students in the high category with average score 60.03 , standard deviation 6.528 of the 80 ideal score with percentage $74.2 \%$. The results of students learning in the good categorized with average score 80.77, standard deviation 6.416 of the 100 ideal score with percentage 53\%. The result of inferential analysis shows that the divergent thinking ability positively and significantly affects the learning results of 0.183 . Self reliance learning also positively and significantly affect the learning results of 0.101 . The results of inferential show that divergent thinking ability and self reliance learning simultaneously influence the results of mathematics learning students with regression equation $\mathrm{Y}=70,119+0,009 \mathrm{X} 1+0,181 \mathrm{X} 2$.
\end{abstract}

Keywords: Divergent Thinking Ability; Self Reliance Learning; Learning Result

\begin{abstract}
Abstrak
Tujuan dari penelitian ini yaitu untuk mengetahui ada tidaknya pengaruh kemampuan berpikir divergen dan kemandirian belajar terhadap hasil belajar matematika siswa. Jenis penelitian yang digunakan dalam penelitian ini adalah jenis penelitian ex-post facto, dengan mengambil sampel dari siswa kelas IX SMPN 24 Makassar sebanyak 102 orang. Instrumen yang digunakan dalam penelitian ini adalah tes kemampuan berpikir divergen, kuesioner kemandirian belajar dan tes hasil belajar matematika. Hasil analisis statistik deskriptif menunjukan bahwa kemampuan berpikir divergen siswa dikategorikan sedang dengan skor ratarata 55,91 dan standar deviasi 10,623 dari skor ideal 100 dengan persentase 42,42\%. Kemandirian belajar siswa berada pada kategori tinggi dengan rata-rata 60,03 dan standar deviasi 6,528 dari skor ideal 80 dengan persentase $74,2 \%$. Sedangkan hasil belajar siswa dikategorikan baik dengan skor rata-rata 80,77 dan standar deviasi 6,416 dari skor ideal 100 dengan persentase 53\%. Hasil analisis inferensial menunjukkan bahwa terdapat pengaruh positif dan signifikan antara kemampuan berpikir divergen terhadap hasil belajar matematika sebesar 0,183 , terdapat pengaruh positif dan signifikan antara kemandirian belajar terhadap hasil belajar matematika sebesar 0,101, serta terdapat pengaruh positif dan signifikan secara simultan antara kemampuan berpikir divergen dan kemandirian belajar terhadap hasil belajar matematika persamaan regresi $\mathrm{Y}=70,119+0,009 \mathrm{X} 1+0,181 \mathrm{X} 2$.
\end{abstract}

Kata Kunci: Berpikir Divergen; Kemandirian Belajar; Hasil Belajar

\section{PENDAHULUAN}

Matematika merupakan ilmu universal yang berguna bagi kehidupan manusia dan juga mendasari perkembangan teknologi modern, serta mempunyai peran penting dalam 


\section{Mandalika Mathematics and Education Journal \\ Volume 2 Nomor 1, Juni 2020 \\ e-ISSN 2715-1190 | | p-ISSN 2715-8292 \\ DOI: http://dx.doi.org/10.29303/mandalika.v2i1.1776}

berbagai disiplin dan memajukan daya pikir manusia. Sundayana (2014:2) menyatakan bahwa matematika merupakan salah satu komponen utama dari serangkaian mata pelajaran. Sehingga mata pelajaran matematika perlu diberikan kepada semua peserta didik mulai dari sekolah dasar, untuk membekali peserta didik dengan kemampuan berpikir logis, analisis, sistematis, kritis dan inovatif, serta kreatif (Maulyda dkk, 2019). Kompetensi tersebut diperlukan agar peserta didik dapat memiliki kemampuan memperoleh, mengelolah, dan memanfaatkan informasi, sebab matematika merupakan alat dan metode berpikir (Tiro, 2010:2).

Berdasarkan hasil observasi dan wawancara langsung dengan guru mata pelajaran matematika di SMPN 24 Makassar pada tanggal 17 Oktober 2018 memaparkan bahwa masih ada beberapa permasalahan yang dihadapi dalam proses belajar mengajar di dalam kelas, seperti halnya yang terjadi di kelas IX SMPN 24 Makassar. Hal itu diamati oleh guru mata pelajaran matematika ketika memberikan soal kepada siswa dengan redaksi kata yang berbeda dengan contoh soal yang telah diberikan sebelumnya dimana masih banyak siswa yang bingung dalam mengerjakannya. Selain itu kebanyakan dari mereka hanya meniru pekerjaan temannya tanpa berusaha mengerjakan sendiri dengan kemampuan dan pemikirannya sendiri. Pada saat ujian banyak dari mereka yang mendapatkan nilai di bawah kriteria ketuntasan minimum.

Permasalahan yang muncul tersebut diyakini bersumber dari ketidakmampuan siswa untuk berpikir divergen dalam menyelesaikan soal matematika. Ketidakmampuan siswa untuk berpikir divergen menyebabkan siswa tidak mampu berpikir kreatif untuk mencari solusi dari persoalan matematika. Hal ini sebagaimana yang diungkapkan oleh Jauk et al (2014:5) yang menyatakan bahwa berpikir divergen merupakan komponen kunci dari proses berpikir kreatif. Demikian pula Runco (2012:66) menyatakan bahwa berpikir divergen mengarahkan kepada berpikir kreatif. Sehingga penting untuk mengetahui bagaimana kondisi kemampuan berpikir divergen siswa dalam belajar matematika. Ni et al (2014:158) menyatakan bahwa kemampuan berpikir divergen merupakan salah satu proses berpikir yang berguna untuk menciptakan ide kreatif dengan mencari berbagai solusi yang mungkin. Berpikir divergen menujuk pada pola berpikir ke segala arah dengan ditandai oleh adanya kelancaran (fluency), kelenturan (flexibility), keaslian (originality), dan elaborasi (elaboration) Munandar dan Utami (Haryanto, 2006:5). Jadi berpikir divergen merupakan ranah berpikir kreatif yang memberikan berbagai kemungkinan jawaban berdasarkan informasi yang diberikan dengan penekanan pada kuantitas, keragaman, dan keaslian jawaban.

Selain kemampuan berpikir divergen, faktor lain yang dapat mempengaruhi hasil belajar siswa adalah kemandirian belajar. Kemandirian merupakan perilaku individu yang mampu berinisiatif, mampu mengatasi masalah, mempunyai rasa percaya diri, bertanggung jawab dan dapat melakukan sesuatu sendiri tanpa bergantung pada orang 


\section{Mandalika Mathematics and Education Journal \\ Volume 2 Nomor 1, Juni 2020 \\ e-ISSN 2715-1190 | | p-ISSN 2715-8292 \\ DOI: http://dx.doi.org/10.29303/mandalika.v2i1.1776}

lain (Mudjiman, 2007:117). Agwagah (2001:40) menyatakan bahwa kemandirian belajar matematika merupakan kemampuan individual yang dimiliki dari belajar matematika untuk belajar sendiri. Khatri \& Dutta (2018:1010) menyatakan bahwa kemampuan berpikir divergent membantu siswa untuk memikirkan sesuatu yang berbeda sehingga memunculkan ide-ide kreatif dalam mencari solusi dan meningkatkan kemampuan problem solving siswa. Bahkan lebih dari itu, Puri (2017:111) menyatakan bahwa kemandirian belajar adalah esensi paling utama yang harus dimiliki jika seorang siswa ingin sukses dalam pembelajarannya. Sehingga kemampuan akan kemandirian dalam belajar sangat diperlukan agar siswa bisa menyelesaikan masalah yang dihadapinya dan mampu mengambil keputusan sendiri dalam mencapai hasil yang lebih baik dengan memunculkan ide-ide yang kreatif dan inovatif.

Penelitian terdahulu yang relevan terkait dengan pengaruh kemampuan berpikir divergen terhadap hasil belajar matematika yaitu penelitian yang dilakukan oleh Upu dkk (2019:26) mengenai pengaruh tipe kepribadian, berpikir divergen, iklim keluarga, dan motivasi terhadap prestasi belajar matematika di SMAN 3 Sinjai, diperoleh hasil bahwa terdapat pengaruh langsung masing-masing antara motivasi, iklim keluarga, dan berpikir divergen terhadap hasil belajar matematika siswa. Demikian pula penelitian yang dilakukan oleh Fatika (2018:67) mengenai pengaruh kemampuan operasi hitung matematika, kemampuan berpikir divergen dan kecerdasan linguistik terhadap hasil belajar matematika siswa di kelas VIII SMP Negeri 1 Sengkang Kabupaten Wajo, diperoleh hasil penelitian bahwa kemampuan berpikir divergen berpengaruh positif dan signifikan terhadap hasil belajar matematika. Beberapa penelitian tersebut mendukung hipotesis bahwa terdapat pengaruh kemampuan berpikir divergen terhadap hasil belajar matematika. Adapun penelitian terdahulu yang relevan terkait dengan pengaruh kemandirian belajar terhadap hasil belajar matematika yaitu penelitian yang dilakukan oleh Ningsih (2016:73) yang menyatakan bahwa terdapat pengaruh positif yang signifikan antara kemandirian belajar dan perhatian orang tua terhadap prestasi belajar matematika. Hasil penelitian tersebut mendukung hipotesis bahwa variabel kemandirian belajar berpengaruh positif terhadap hasil belajar matematika.

Tujuan dari penelitian ini yaitu untuk mengetahui ada tidaknya pengaruh kemampuan berpikir divergen siswa terhadap hasil belajar matematika siswa, pengaruh kemandirian belajar siswa terhadap hasil belajar matematika siswa, dan pengaruh kemampuan berpikir divergen dan kemandirian belajar secara bersama-sama terhadap hasil belajar matematika siswa di kelas IX SMP Negeri 24 Makassar

\section{METODE}

Jenis penelitian adalah ex-post facto yang dilakukan untuk meneliti peristiwa yang telah terjadi dan kemudian merunut ke belakang untuk mengetahui faktor-faktor yang dapat menimbulkan peristiwa tersebut (Creswell, 2012). Bertindak sebagai peneliti adalah 


\section{Mandalika Mathematics and Education Journal \\ Volume 2 Nomor 1, Juni 2020 \\ e-ISSN 2715-1190 | | p-ISSN 2715-8292 \\ DOI: http://dx.doi.org/10.29303/mandalika.v2i1.1776}

dosen bersama mahasiswa dengan tujuan penelitian untuk mengetahui sejauh mana variabel-variabel bebas mempengaruhi variabel terikat. Variabel-variabel yang diteliti yaitu kemampuan berpikir divergen (X1), kemandirian belajar (X2), dan hasil belajar matematika (Y). Populasi dalam penelitian ini adalah kelas IX SMPN 24 Makassar yang terdiri dari tiga kelas dengan jumlah siswa sebanyak 102 siswa, sampel yang diambil sebanyak 66 siswa. Penentuan sampel dilakukan dengan cara apabila kurang dari atau sama dengan 100 orang maka semua sampel diambil, namun jika jumlah subjek lebih dari 100 orang, maka diambil antara 10\%-15\% atau 20\%-25\% dari populasi. Instrumen yang digunakan dalam penelitian ini adalah tes dan angket. Pengumpulan data dilakukan dengan pemberian tes kemampuan berpikir divergen dan kuesioner kemandirian belajar serta tes hasil belajar matematika siswa. Pemberian tes dilakukan satu kali. Selanjutnya skor yang terkumpul pada tes tersebut dianalisis menggunakan analisis statistik deskriptif dan analisis inferensial.

\section{HASIL DAN PEMBAHASAN}

Hasil tes yang dilakukan terhadap 66 orang ditunjukkan dalam tabel 1, diperoleh mean sebesar 55,91 dari skor ideal 100 dengan standar deviasi 10,62 dan median 57,00. Hal ini menunjukkan bahwa tidak terjadinya outlier pada data karena nilai standar deviasi lebih kecil daripada nilai mean, untuk nilai minimum dan maksimum masing-masing sebesar 35 dan 79. Selain itu, hasil untuk angket kemandirian belajar dilakukan terhadap 66 orang diperoleh nilai mean atau rata-rata sebesar 60,03 dari skor ideal 80 dengan standar deviasi 6,53 dan median sebesar 60,00. Hal ini menunjukkan bahwa tidak terjadinya outlier pada data karena nilai standar deviasi lebih kecil daripada nilai rata-rata, untuk nilai minimum dan maksimum masing-masing sebesar 43 dan 72 .

Tabel 1. Ringkasan Statistik Deskriptif

\begin{tabular}{lccc}
\hline \multirow{2}{*}{ Statistik } & \multicolumn{3}{c}{ Variabel } \\
\cline { 2 - 4 } & $\mathbf{X}_{\mathbf{1}}$ & $\mathbf{X}_{\mathbf{2}}$ & $\mathbf{Y}$ \\
\hline Rata-rata & 55,91 & 60,03 & 80,77 \\
Median & 57,00 & 60,00 & 81,00 \\
Variansi & 112,85 & 42,61 & 41,16 \\
Standar Deviasi & 10,62 & 6,53 & 6,42 \\
Maksimum & 79,00 & 72,00 & 90,00 \\
Minimum & 35,00 & 43,00 & 68,00 \\
\hline \multicolumn{3}{c}{ Sumber: Hasil olah data }
\end{tabular}

Berdasarkan tabel 2, diketahui bahwa kemampuan berpikir divergen kelas IX SMP Negeri 24 Makassar berada pada kategori rendah, sedang, dan tinggi dengan persentase masing-masing 34,9\% dengan frekuensi 11 orang responden, 42,4\% dengan frekuensi 28 orang responden, dan $22,7 \%$ dengan frekuensi 15 responden. 
Tabel 3. Distribusi Frekuensi Skor Kemandirian Belajar

\begin{tabular}{clcc}
\hline Interval Skor & \multicolumn{1}{c}{ Kategori } & Frekuensi & Persentase \\
\hline $20<\mathrm{KB} \leq 32$ & Sangat Rendah & 0 & $0,0 \%$ \\
$32<\mathrm{KB} \leq 44$ & Rendah & 1 & $1,5 \%$ \\
$44<\mathrm{KB} \leq 56$ & Sedang & 11 & $16,7 \%$ \\
$56<\mathrm{KB} \leq 68$ & Tinggi & 49 & $74,2 \%$ \\
$68<\mathrm{KB} \leq 80$ & Sangat Tinggi & 5 & $7,6 \%$ \\
Jumlah & & 66 & $100 \%$ \\
\hline
\end{tabular}

Berdasarkan tabel 3 diketahui bahwa kemandirian belajar siswa kelas IX SMP Negeri 24 Makassar berada pada kategori rendah, sedang, tinggi dan sangat tinggi dengan persentase masing-masing 1,5\% dengan frekuensi 1 orang responden, 16,7\% dengan frekuensi 11 orang responden, 74,2\% dengan frekuensi 49 orang responden dan 7,6\% dengan frekuensi 5 orang responden.

Tabel 4. Distribusi Frekuensi Skor Hasil Belajar

\begin{tabular}{llcc}
\hline \multicolumn{1}{c}{ Nilai Interval } & \multicolumn{1}{c}{ Kategori } & Frekuensi & Persentase \\
\hline $86-100$ & Sangat Baik (A) & 19 & $28,8 \%$ \\
$71-85$ & Baik (B) & 35 & $53,0 \%$ \\
$56-70$ & Cukup (C) & 10 & $15,2 \%$ \\
$\leq 55$ & Kurang (D) & 2 & $3,0 \%$ \\
Jumlah & & 66 & $100 \%$ \\
\hline
\end{tabular}

Berdasarkan tabel 4, hasil belajar matematika siswa kelas IX SMP Negeri 24 Makassar berada pada kategori Baik (B) dengan persentase 53\% dengan frekuensi 35 siswa. Statistika inferensial digunakan untuk pengujian hipotesis, namun sebelum dilakukan pengujian hipotesis terlebih dahulu dilakukan uji prasyarat yaitu uji normalitas, uji linearitas, uji multikolinearitas, dan uji autokorelasi serta uji heterokedastisitas. Setelah uji prasyarat terpenuhi pengujian hipotesis dapat dilanjutkan.

Tabel 5. Uji Signifikan Parameter Individu (Uji Statistik t)

\begin{tabular}{lllll}
\hline & $\begin{array}{l}\text { Unstandardized } \\
\text { Coefficients }\end{array}$ & $\begin{array}{l}\text { Standardized } \\
\text { Coefficients }\end{array}$ & \\
\cline { 2 - 5 } Model & B & Beta & T & Sig. \\
\hline (Constant) & 70,119 & & 9,495 & 0,000 \\
Kemampuan Berpikir & 0,009 & 0,009 & 2,071 & 0,044 \\
$\begin{array}{l}\text { Divergen } \\
\text { Kemandirian Belajar }\end{array}$ & 0,181 & 0,300 & 2,372 & 0,021 \\
\hline
\end{tabular}

Berdasarkan tabel 5, diketahui nilai sig. 2 tailed) adalah kemandirian belajar sebesar $0,021<0,05$ dan kemampuan berpikir divergen sebesar 0,044<0,05 serta nilai t hitung kemandirian belajar sebesar 2,071 > t tabel = 1,696 dan $\mathrm{t}$ hitung kemampuan berpikir divergen sebesar 2,372 $>\mathrm{t}$ tabel $=1,696$, maka sesuai dengan dasar pengambilan keputusan uji t dapat disimpulkan bahwa ada pengaruh positif dan signifiakn variabel 


\section{Mandalika Mathematics and Education Journal \\ Volume 2 Nomor 1, Juni 2020 \\ e-ISSN 2715-1190 | | p-ISSN 2715-8292 \\ DOI: http://dx.doi.org/10.29303/mandalika.v2i1.1776}

kemandirian belajar terhadap hasil belajar dan kemampuan berpikir divergen terhadap hasil belajar.

Tabel 6. Uji Signifikan Simultan

\begin{tabular}{llllll}
\hline Model & Sum of Squares & df & Mean Square & F & Sig. \\
\hline Regression & 245,212 & 2 & 122,606 & 3,178 & $0,048^{\mathrm{b}}$ \\
Residual & 2430,379 & 63 & 38,577 & & \\
Total & 2675,591 & 65 & & & \\
\hline
\end{tabular}

Berdasarkan tabel 6, diperoleh nilai sig. sebesar 0,048 dan $\mathrm{F}$ hitung sebesar 3,178, karena nilai sig. 0,048<0,05, dan nilai $\mathrm{F}$ hitung $>\mathrm{F}$ tabel $(3,178>3,15)$, maka sesuai dengan dasar pengambilan keputusan dalam uji $\mathrm{F}$ dapat disimpulkan bahwa variabel kemampuan berpikir divergen (X1) dan kemandirian belajar (X2) signifikan secara bersama sama terhadap variabel hasil belajar $(\mathrm{Y})$.

\section{Tabel 7. Hasil Uji Koefisien Determinasi}

\begin{tabular}{lllll}
\hline Model & R & R Square & Adjusted R Square & Std. Error of the Estimate \\
\hline 1 & $0,763^{\mathrm{a}}$ & 0,582 & 0,063 & 6,211 \\
\hline
\end{tabular}

Dari tabel 7, diketahui bahwa nilai $\mathrm{R}$ adalah 0,763 , sedangkan nilai $\mathrm{R} 2$ sebesar 0,582. Oleh karena uji koefisien determinasi berganda ini diperoleh dari perhitungan regresi ganda, maka koefisien determinasi sebesar 0,582 atau R2 x 100\% sebesar 58,2\%. Kebermaknaan dari nilai tersebut memiliki implikasi bahwa variabel kemampuan berpikir divergen dan kemandirian belajar berpengaruh positif yang signifikan terhadap hasil belajar matematika siswa kelas IX SMP Negeri 24 Makassas sebesar 58,20\%, dan sisanya 41,20\% dipengaruhi oleh variabel-variabel lain di luar dari variabel dalam penelitian ini.

Berdasarkan hasil analisis data dan perhitungan regresi linear sederhana kemampuan berpikir divergen berpengaruh positif yang signifikan terhadap hasil belajar matematika. Hal ini dapat terlihat pada nilai sig. sebesar 0,014. Karena nilai signifikan sebesar 0,014 $<0,05$, maka sesuai dasar pengambilan keputusan dalam pengujian variabel kemampuan berpikir divergen berpengaruf positif yang signifikan terhadap hasil belajar. Selain itu, berdasarkan perbandingan $t$ hitung dan $t$ tabel diperoleh $t$ hitung sebesar 2,540 $>t$ tabel sebesar 1,696, hail ini menunjukkan bahwa kemampuan berpikir divergen berpengaruh positif secara signifikan terhadap hasil belajar matematika. Adapun hasil uji linearitas diperoleh nilai Deviation From Linerity Sig. adalah 0.097>0.05, yang berarti bahwa ada hubungan linear antara kemampuan berpikir divergen dan hasil belajar.

Hasil penelitian menunjukkan bahwa kemampuan berpikir divergen berpengaruh positif dan signifikan terhadap hasil belajar relevan dengan hasil penelitian terdahulu yang dilakukan oleh Fatika (2018: 67) yang menyatakan bahwa adanya pengaruh positif yang signifikan kemampuan berpikir divergen terhadap hasil belajar siswa. Selanjutnya, penelitian yang releven dilakukan oleh Wahyuni (2016:76) yang menyatakan bahwa 


\section{Mandalika Mathematics and Education Journal \\ Volume 2 Nomor 1, Juni 2020 \\ e-ISSN 2715-1190 | | p-ISSN 2715-8292 \\ DOI: http://dx.doi.org/10.29303/mandalika.v2i1.1776}

terdapat pengaruh positif yang signifikan kemampuan berpikir divergen terhadap hasil belajar matematika. Dari uraian di atas dapat disimpulkan bahwa kemampuan berpikir divergen dapat berpengaruh positif yang signifikan terhadap hasil belajar matematika, sehingga kemampuan berpikir divergen siswa perlu dikembangkan lagi agar hasil belajar siswa dapat lebih maksimal.

Berdasarkan analisis data dan perhitungan regresi linear sederhana kemandirian belajar berpengaruh positif secara signifikan terhadap hasil belajar matematika. Hal ini dapat terlihat pada nilai sig. sebesar 0,041. Karena nilai sig. sebesar 0,041<0,05, maka sesuai dengan dasar pengambilan keputusan dalam pengujian terdapat pengaruh positif kemandirian belajar terhadap hasil belajar matematika. Selain itu, berdasarkan perbandingkan $\mathrm{t}$ hitung dengan $\mathrm{t}$ tabel, dimana diperoleh $\mathrm{t}$ hitung sebesar 2,826 $>\mathrm{t}$ tabel sebesar 1,696, hal ini menunjukkan bahwa terdapat pengaruh positif yang signifikan kemandirian belajar terhadap hasil belajar. Adapun hasil uji linearitas diperoleh nilai Deviation From Linerity Sig. adalah 0,725>0,05, yang berarti bahwa ada hubungan linear antara kemandirian belajar dan hasil belajar.

Berdasarkan hasil uji signifikan simultan (uji F) diperoleh nilai sig. sebesar 0,048 dan nilai $\mathrm{F}$ hitung sebesar 3,178. Dimana nilai sig. sebesar 0,048 $<0,05$, dan perbandingan nilai $\mathrm{F}$ hitung $>\mathrm{F}$ tabel $(3,178>3,15)$, maka sesuai dengan dasar pengambilan keputusan dalam uji $\mathrm{F}$ dapat disimpulkan bahwa variabel kemampuan berpikir divergen (X1) dan kemandirian belajar (X2) signifikan secara bersama-sama terhadap variabel hasil belajar (Y). Selanjutnya, berdasarkan hasil uji t diperoleh nilai sig. (2 tailed) yaitu kemampuan berpikir divergen sebesar 0,021 <0,05 dan kemandirian belajar sebesar 0,044<0,05 serta nilai t hitung kemampuan berpikir divergen sebesar 2,372 dan nilai t hitung kemandirian belajar sebesar 2,071, jika dibendingkan dengan t tabel maka nilai t hitung kemampuan berpikir divergen $>\mathrm{t}$ tabel $(2,372>1,696)$ dan nilai t hitung kemandirian belajar $>\mathrm{t}$ tabel $(2,071>1,696)$, sehingga sesuai dengan dasar pengambilan keputusan uji t dapat disimpulkan bahwa ada pengaruh variabel kemampuan berpikir divergen (X1) dan kemandirian belajar (X2) terhadap hasil belajar (Y).

Adapun analisis data dan perhitungan regresi ganda kemampuan berpikir divergen dan kemandirian belajar siswa (X1 dan X2) dengan hasil belajar matematika (Y) diperoleh persamaan regresi $\mathrm{Y}=70,119+0,009 \mathrm{X} 1+0,181 \mathrm{X} 2$ dengan melihat nilai $\mathrm{p}$ lebih kecil dari nilai $\alpha$ yaitu $0,048<0,05$. Hal ini menunjukkan bahwa terdapat pengaruh signifikan secara bersama-sama antara kemampuan berpikir divergen dan kemandirian belajar siswa kelas IX SMP Negeri 24 makassar, dimana setiap kenaikan satu unit X1 akan mengakibatkan 0,009 unit kenaikan Y dan kenaikan satu unit X2 akan mengakibatkan 0,181 unit kenaikan Y. Jadi semakin tinggi kemampuan berpikir divergen maka semakin tinggi pula hasil belajar,dan semakin tinggi kemandirian belajar siswa maka semakin tinggi juga hasil belajar siswa. Besarnya koefisien determinasi (R2) adalah 0,582. Hal ini 


\section{Mandalika Mathematics and Education Journal \\ Volume 2 Nomor 1, Juni 2020 \\ e-ISSN 2715-1190 | | p-ISSN 2715-8292 \\ DOI: http://dx.doi.org/10.29303/mandalika.v2i1.1776}

berarti besarnya pengaruh kemampuan berpikir divergen dan kemandirian belajar terhadap hasil belajar matematika siswa adalah sebesar 58,20\%. Dengan demikian hipotesis ketiga yang menyatakan terdapat pengaruh kemampuan berpikir divergen dan kemandirian belajar siswa terhadap hasil belajar matematika dapat diterima. Sehingga dari uraian di atas dapat disimpulkan bahwa terdapat pengaruh positif yang signifikan kemampuan berpikir divergen dan kemandirian belajar secara bersama-sama terhadap hasil belajar matematika. Artinya kedua faktor yang mempengaruhi hasil belajar matematika harus terus dikembangkan agar hasil belajar matematika dapat lebih baik lagi.

\section{PENUTUP}

Berdasarkan hasil penelitian dan pengujian hipotesis, dapat disimpulkan bahwa terdapat pengaruh positif dan signifikan kemampuan berpikir divergen terhadap hasil belajar matematika, setiap kenaikan satu unit kemampuan berpikir divergen akan meningkatkan sebesar 0.183 unit secara signifikan hasil belajar matematika. Terdapat pengaruh positif dan signifikan kemandirian belajar terhadap hasil belajar matematika, setiap kenaikan satu unit kemandirian belajar akan meningkatkan sebesar 0.101 unit secara signifikan hasil belajar matematika. Terdapat pengaruh positif dan signifikan kemampuan berpikir divergen dan kemandirian belajar terhadap hasil belajar matematika, besar sumbangan kemampuan berpikir divergen dan kemandirian belajar secara simultan terhadap hasil belajar matematika sebesar $58,2 \%$ sisanya sebesar $41,8 \%$ disumbang oleh variabel-variabel lain selain kemampuan berpikir divergen dan kemandirian belajar.

Dari hasil penelitian disarankan agar guru memberikan motivasi kepada siswa untuk lebih mengembangkan kemampuan berpikir divergennya serta membangkitkan kemandirian belajar siswa agar memperoleh hasil belajar yang lebih baik lagi, bagi siswa diharapkan dapat memotivasi dirinya sendiri untuk mengembangkan kemampuan berpikir divergen serta belajar mandiri dengan menetapkan target dalam belajar, dan bagi peneliti untuk melakukan penelitian lanjutan mengenai kemampuan berpikir divergen dan kemandirian belajar siswa terhadap hasil belajar.

\section{REFERENSI}

Agwagah, U.N.V. (2001). Making Mathematics Education Self-Reliant. Journal of Science and Comuter Education. Vol 1(3), 36-37 
Creswell, J. W. (2012). Educational research: Planning, conducting, and evaluating quantitative and qualitative research (4th ed.) (4th ed.). Boston, MA: Pearson

Fatika, Y.D. (2018). Pengaruh Kemampuan Operasi Hitung Matematika, Kemampuan Berpikir Divergen, dan Kecerdasan Linguistik terhadap Hasil Belajar Siswa Kelas VIII SMP Negeri 1 Sengkang Kabupaten Wajo, Skripsi. Makassar: Universitas Muhammadiyah Makassar

Haryanto. (2006). Pengembangan Cara Berpikir Divergen-Konvergen sebagai Isu Kritis dalam Proses Pembelajaran. Majalah Ilmiah Pembelajaran. Vol 2, 1

Jauk, E., Benedek, M., \& Neubauer, A. C. (2014). The Road to Creative Achievement; A latent variable model of ability and personality predictors. European Journal of Personality. 1(28). Doi : https://doi.org/10.1002/per.1941.

Khatri, P., \& Dutta, S. (2018). Divergent Thinking - It's Time to Change The Box. Research Review International Journal of Multidisciplinary. 3(10): 1004-1011

Maulyda, M. A., Hidayati, V. R., Rosyidah, A. N. K., \& Nurmawanti, I. (2019). Problem-solving ability of primary school teachers based on Polya's method in Mataram City. PYTHAGORAS: Jurnal Pendidikan Matematika, 14(2), 139-149.

Mudjiman, H. (2007). Belajar Mandiri (Self-Motivated Learning). Surakarta: UNS Press.

Ni, M., Yang, L., Chen, J., Chen, H., Li, X. (2014). How to Improve Divergent Thinking Capability by Information Technology and Extenics. 31(2014): 158-164. Doi: 10.1016/j.procs.2014.05.256..

Ningsih, R., \& Nurrahmah, A. (2016). Pengaruh Kemandirian Belajar dan Perhatian Orang Tua terhadap Prestasi Belajar Matematika. Journal Formatif. 6(1): 73-84. Doi: http://dx.doi.org/10.30998/formatif.v6i1.754.

Puri, A. (2017). Self Reliance in Relation to Learning Style of High School Students. International Education \& Research Journal (IERJ). 3(5): 110-111.

Runco, M. A., \& Acar, S. (2012). Divergent Thinking As An Indicator of Creative Potential. Creativity Research Journal. 24(1): 66-75. Doi: 10.1080/10400419.201.

Sundayana, R. (2014). Media dan Alat Peraga dalam Pembelajaran Matematika (Untuk Guru, Calon Guru, Orang Tua, dan Para Pecinta Matematika). Bandung: Alfabeta.

Tiro, M. A. (2010). Cara Efektif Belajar Matematika. Makassar: Andira Publisher.

Upu, H., Nasrullah, \& Amir, A.A. (2019). Pengaruh Tipe Kepribadian, Berpikir Divergen, Iklim Keluarga, dan Motivasi terhadap Prestasi Belajar Matematika Siswa SMAN 3 Sinjai. Journal Eprints

Wahyuni, T. (2016). Pengaruh Sikap, Kemampuan Verbal, Motivasi Berprestasi, Kedisiplinan, Kemampuan Berpikir Divergen dan Minat Belajat terhadap Hasil Belajar Siswa Kelas X SMK Negeri 2 Takalar. Skripsi. Makassar: Universitas Negeri Makassar 